${ }^{4}$ Shackelford, P G, et al, American fournal of Diseases of Children, 1977, 131, 391.

5 Visintine, A M, et al, American Fournal of Diseases of Children, 1977, 131, 393.

(Accepted 11 April 1978)

Departments of Infectious Diseases, Bacteriology, Paediatrics, and Obstetrics and Gynaecology, University of Lund, General Hospital, Malmö, Sweden

S LARSSON, MD, consultant in infectious diseases

A CEDERBERG, $M D$, bacteriologist

$S$ IVARSSON, MD, paediatrician

L SVANBERG, MD, assistant professor of obstetrics

$S$ CRONBERG, MD, assistant professor and head of department of

infectious diseases evidently experienced considerable pain. Although the initial pain rapidly subsided, Houdini was kept awake that night with what he took to be a torn muscle. Fever supervened and after a further three days his surgeons found a gangrenous appendix and advanced of peritonitis, from which he succumbed.

Historical diagnosis is a fashionable exercise and I suggest that Houdini's biographers ${ }^{4}$ were the first to document an isolated injury $\varrho$ to the appendix after blunt abdominal trauma.

I thank Mr D C Britton for permission to report this case.

1 Geer, D A, et al, Archives of Surgery, 1975, 110, 446.

2 Gatewood, J W, and Russum, W J, American fournal of Surgery, 1956, 91, 558.

3 Burgess, C M, fournal of the American Medical Association, 1938, 111, 699. है 4 Gresham, W L, Houdini. London, Gollancz, 1960.

(Accepted 23 May 1978)

Royal United Hospital, Bath BA1 3NG

D F M THOMAS, MRCP, FRCS, surgical registrar

\section{Injury to the appendix after blunt abdominal trauma}

Traumatic rupture of the appendix as an isolated visceral injury is exceptionally rare and appears to be unrecorded in Great Britain. This paper reports such a case, speculates on the mechanism of injury, and adds an historical note.

\section{Case report}

A healthy 36-year-old lorry driver sustained a low velocity crush injury as he was trapped between a stationary and a slow moving vehicle. The patient remained conscious throughout the incident and could subsequently describe a combination of compression and rotation forces applied to the lower thorax and upper abdomen. Examination in the casualty department showed tenderness of the abdomen and left loin. Bowel sounds were present and there were no signs of peritoneal irritation. Microscopic haematuria was detected on reagent strip testing. The only abnormalities seen on $x$-ray examination were fractures of the left transverse processes of the second, third, and fourth lumbar vertebrae. In the absence of convincing evidence of visceral injury he was initially admitted for observation but when, after four hours, he complained of right shoulder tip pain he was submitted to laparotomy.

The abdomen was opened through a right paramedian incision and a little free blood was immediately evident lying in the right paracolic gutter. The source of the bleeding was identified as a long, torn mesoappendix-the appendix itself having been completely severed at the junction of its proximal third and distal two-thirds. The severed portion was located near the hepatic flexure. No other visceral injury was found, although there was considerable retroperitoneal haematoma in the left perinephric region. The proximal portion of the appendix was excised and the stump invaginated to complete the appendicectomy. The patient made an uncomplicated recovery and was discharged on the sixth day.

Histological examination of the appendix showed a small faecolith in the severed portion and mild but definite inflammatory changes confined to the mucosa of both portions. Despite the patient's freedom from symptoms before the accident, the features were those of an early (subclinical) acute appendicitis.

\section{Comment}

Avulsion or rupture of the appendix is exceedingly rare and case reports appear to be confined to the American journals. In 1975 Geer et $a l^{1}$ described one case but could find only another two reports. ${ }^{2} 3$ The precise mechanism of these injuries is speculative, but in two ${ }^{12}$ it was apparently related to deceleration forces while the third patient ${ }^{3}$ presented with signs of acute appendicitis after avulsion of the tip of the appendix resulting from the action of a pneumatic drill resting on the right iliac fossa. In my patient the early inflammatory changes in the appendix probably rendered it less able to withstand shearing and compression forces which left the other more supple viscera intact.

Reports agree that the diagnosis will usually be made only at laparotomy and that the treatment is appendicectomy. Houdini, the legendary escapologist, would invite blows to his abdomen to demonstrate his remarkable strength and physique. On one occasion in 1926 he was unprepared for a punch thrown by an amateur boxer and

\section{Squamous cell carcinoma of bronchus presenting with Henoch-Schönlein purpura}

The antigen precipitating an episode of Henoch-Schönlein purpura frequently remains unidentified. ${ }^{1}$ We have seen two patients with squamous cell carcinoma of the bronchus in whom a tumour antigen may have initiated an attack.

\section{Case reports}

Case 1-A 63-year-old man developed polyarthritis and a purpuric rash in November 1975. He had chronic bronchitis but had had no recent chest infections. His urine contained red cells, casts, and up to $7 \mathrm{~g}$ of protein a day. His platelet count and serum complement concentrations were normal. A chest $x$-ray film showed only emphysematous change. No organism was cultured from throat swabs or sputum. The antistreptolysin O (ASO) titre was normal. Serum IgA concentration was $2 \mathrm{~g} / 1$ (normal range $1 \cdot 4-4 \mathrm{~g} / 1$ ). The rash and arthritis resolved over three weeks but heavy proteinuria and microscopic haematuria persisted. A renal biopsy specimen obtained in May 1976 showed mesangial proliferation with IgA and IgG deposits. By July the proteinuria had resolved but haematuria persisted and the creatinine clearance had fallen to $40 \mathrm{ml} / \mathrm{min}$, from $60 \mathrm{ml} / \mathrm{min}$ in March. A chest $x$-ray film now showed a thick-walled cavity at the apex of the right lower lobe. Sputum cytology was suggestive of squamous cell carcinoma. Thoracotomy or was not undertaken because of his chronic airways disease. By the time of his death from carcinomatosis in July 1977 the haematuria had resolved but his creatinine clearance had fallen to $30 \mathrm{ml} / \mathrm{min}$. He had had no further episodes of Henoch-Schönlein purpura. Postmortem examination confirmed the diagnosis of squamous cell carcinoma of the bronchus.

Case 2-A 73-year-old man presented in August 1973 with oedema of the hands and feet, polyarthralgia, and purpura. He had abdominal colic and melaena stools. He was a heavy smoker with a history of chronic bronchitis and recent weight loss and haemoptysis. Apart from antibiotics for a "chill" nine weeks previously he had no recent history of infection or drug ingestion. His urine contained numerous red cells and granular casts, and he developed up to $3 \mathrm{~g}$ of proteinuria per day. Throat swab, sputum, and blood cultures grew no organism. The ASO titre was normal and the results of virological studies were negative. The platelet count and serum complement concentrations were normal. The serum IgA was $4 \cdot 1 \mathrm{~g} / \mathrm{l}$. The chest $x$-ray film showed persistent consolidation in the left upper lobe, and the sputum contained malignant cells. A skin biopsy specimen showed an acute allergic necrotising vasculitis. In a renal biopsy specimen there was focal proliferative glomerulonephritis with IgA deposition and immune complexes in the mesangium. The purpura and arthralgia resolved but proteinuria and haematuria persisted. A left upper lobectomy was performed in November 1973 and a squamous cell carcinoma of the bronchus removed. The proteinuria and haematuria rapidly resolved after the operation and the creatinine clearance rose from $31 \mathrm{ml} / \mathrm{min}$ to $60 \mathrm{ml} / \mathrm{min}$. The patient died from a local recurrence of his tumour in August 1975. He had had no further episodes of HenochSchönlein purpura or nephritis. 


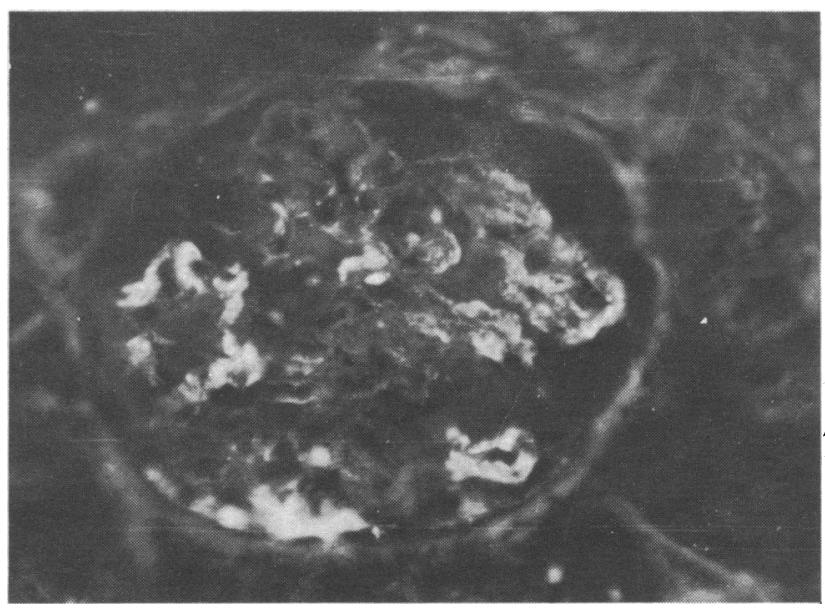

Renal biopsy specimen, case 2 . Mesangial deposits of IgA largely confined to the mesangial regions with some segmental variation (FITC-labelled anti-IgA. $\times 300$.

\section{Comment}

Tumours may give rise to circulating immune complexes, and tumour-specific antibodies and antigens have been found in these complexes. $^{2-4}$ It has been suggested that Henoch-Schönlein purpura is mediated by immune complexes containing $\operatorname{IgA},{ }^{5}$ and the condition may have occurred in our patients as a result of a carcinoma, which, acting as a source of new antigens arising at an endothelial surface, provoked an IgA response. That the renal lesion in case 2 resolved on resection of the tumour would support this assumption, and there is no evidence of another source of antigen in either case. That only one episode of purpura occurred in each case may be due to factors.in host or tumour which resulted in only a transient IgA response of suitable quality or quantity for soluble immune complex formation.

We thank Mrs P Tarpey and Mrs S Green for technical help.

${ }^{1}$ Cream, J J, et al, Quarterly fournal of Medicine, 1970, 39, 461.

2 Gagliano, R S, et al, American fournal of Medicine, 1976, 60, 1026.

3 Lewis, M G, et al, Lancet, 1971, 2, 134.

${ }^{4}$ Costanza, M E, et al, New England fournal of Medicine, 1974, 289, 520

5 Trygstad, C W, and Stiehm, E R, Pediatrics, 1971, 47, 1023.

(Accepted 7 fune 1978)

Department of Renal Medicine, Manchester Royal Infirmary

S A CAIRNS, BSC, MRCP, tutor in medicine

N P MALLICK, BSC, FRCP, consultant physician

Department of Pathology, University of Manchester

W LAWLER, MB, CHB, lecturer in pathology

G WILLIAMS, MD, FRCPATH, reader in pathology

\section{Menarcheal age in the disabled}

Studies among normal populations have shown multifactorial influences on the age of menarche (economic, nutritional, geographical, social, and weight). Nevertheless, few studies have considered the mean menarcheal age (MMA) in handicapped girls other than the blind. We describe such a study.

\section{Subjects, method, and results}

Blind, deaf, and physically handicapped girls attending special schools in England and Wales completed forms stating the date of birth, particulars of disability, and date of first menstruation. Girls attending schools for physically handicapped had a heterogenous collection of severe disabilities including neural tube deformities, cerebral palsy, spasticity, epilepsy, blood dyscrasias, asthma, and cardiac lesions.
MMA of girls attending special schools on list 42 of the Department of Education

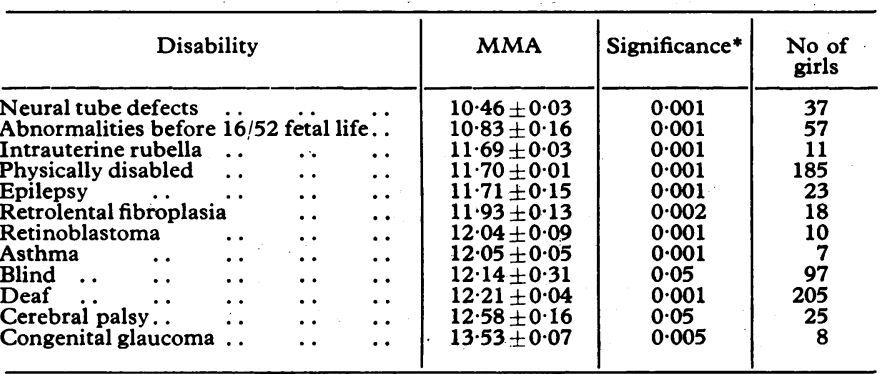

*Students $t$ test against normal London schoolgirls.

The MMA was calculated by the probit method, as recommended by Tanner. ${ }^{1}$ The table compares the MMA of normal London schoolgirls at 13.1 years with the earlier MMA of the blind, deaf, and physically handicapped groups. The MMA was particularly early among those with neural tube deformities, abnormalities arising before the 16th week of fetal life, and intrauterine rubella, but a late MMA was found among those with congenital glaucoma. We appreciate that some of the disease groups contained small numbers and further studies are indicated.

\section{Comment}

The menarche represents the onset of sexual maturity in girls. In normal populations the MMA varies from 12.4 in Cuban negroes to 18.8 in the Bundi tribe of New Guinea. ${ }^{1}$ Precocious puberty is recognised to occur among those with disease or anomalies of the central nervous system and we have confirmed that girls with neura tube deformities had a MMA of 10.46. Burrow et $a l^{2}$ noted that girls exposed to intrauterine radiation from the atomic bomb at Nagasak had their MMA slightly delayed, but those whose irradiation occurred during the first trimester of pregnancy had an earlier menarche compared with those irradiated in the second and third trimester.

Bellone $^{3}$ found a delayed MMA in infants with a birth weight below 2500 g. Nevertheless, in this study the 18 girls with retrolental fibroplasia due to prematurity and exposure to high oxygen concentrations in the neonatal period had an early MMA at 11.9. The earlier MMA noted among the blind has been attributed to the deprivation of light or light perception, ${ }^{4}$ but the early MMA in other groups of handicapped girls suggests that light is not the only relevant factor. Possibly the administration of steroids to girls with congenital adrenal hyperplasia may delay the menarche, ${ }^{5}$ but the seven girls whose asthma was of such severity that they required education at specia schools had an early MMA at 12.05 and would have had steroid treatment (albeit intermittent and not necessarily from the neonatal period).

The finding of an early MMA among those attending special schools is of practical importance. In Great Britain normal children transfer to secondary schools at the age of 11 , whereas girls at special schools transfer at 12 , when the majority are already menstruating. In Britain there is little sex education at primary schools, which is when these handicapped girls need it most.

We thank the staff and girls at the special schools for their co-operation and Dr Peter Freeman of University College, London, for his statistical help.

${ }^{1}$ Hiernaux, J, Eugenic Quarterly, 1968, 15, 12.

2 Burrow, G N, Hamilton, H B, and Hrubec, Z, Fournal of the American Medical Association, 1965, 192, 357.

3 Bellone, F, Minerva Ginecologica, 1975, 27, 515.

4 Zacharias, L, and Wurtman, R J, Science, 1964, 144, 1154.

5 Prader, A, Tanner, J M, and von Harnack, G A, fournal of Pediatrics, $1963,62,646$.

(Accepted 14 fune 1978)

Department of Gynaecology, Jessop Hospital, Sheffield

MAUREEN E DALTON, MB, BS, senior house officer

Department of Psychological Medicine, University College Hospital, London

KATHARINA DALTON, MRCGP, clinical assistant 